ARTIGO DE REVIS ÃO

\section{MECHANISMS OF ACTION OF}

BALNEOTHERAPY IN RHEUMATIC DISEASES: THE SCIENTIFIC EVIDENCE

\section{MECANISMOS DE AÇÃO DA BALNEOTERAPIA NAS DOENÇAS REUMÁTICAS: AS EVIÊNCIAS CIENTÍFICAS}

\section{ABSTRACT}

Balneotherapy represents a treatment widely used in many rheumatic diseases (RD). The mechanisms by which immersion in mineral or thermal water ameliorates RD are not fully understood. The beneficial effect of balneotherapy has probably a multifactorial nature.Buoyancy, immersion, resistance and temperature all play important roles. According to the gate theory, pain relief may be due to the pressure and temperature of the water on skin; hot stimuli may influence muscle tone and pain intensity, helping to reduce muscle spasm and to increase the pain threshold. Mud-bath therapy increases plasma $\beta$-endorphin levels and secretion of corticotrophin, cortisol, growth hormone and prolactin. It has recently been demonstrated that thermal mud-bath therapy induces a reduction in circulating levels of Prostaglandin E2 (PGE2), Leukotriene B4 (LTB4), Interleukin-1 $\beta$ (IL-1 $\beta$ ) and Tumour Necrosis Factor- $\alpha$ (TNF- $\alpha$ ), important mediators of inflammation and pain. Furthermore, balneotherapy has been found to cause an increase in Insulin-like Growth Factor-1 (IGF1), which stimulates cartilage metabolism, and Transforming Growth Factor- $\beta$ (TGF- $\beta$ ). Beneficial anti-inflammatory and anti-degenerative effects of mineral water were confirmed in chondrocytes cultures, too. It has been also shown the positive action of mud-packs and thermal baths on the oxidant/antioxidant system, with a reducing release of reactive oxygen (ROS) and nitrogen (RNS) species. Overall, thermal stress has an immunosuppressive effect.

Many other non-specific factors may also contribute to the beneficial effects observed after balneotherapy in some $\mathrm{RD}$, including effects on cardiovascular risk factors and changes in the environment, pleasant surroundings and the absence of work duties.

\section{KEY WORDS}

Balneotherapy.

Spa therapy.

Rheumatic diseases.

Mechanisms of action.

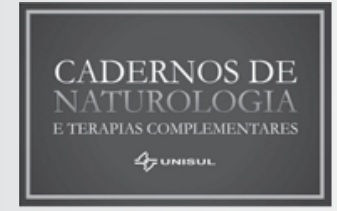

Antonella Fioravanti ${ }^{1}$

Sara Cheleschi ${ }^{2}$

Sara Tent ${ }^{1}$

1 MD Rheumatology Unit, Department of Medicine, Surgery and Neuroscience, University of Siena, Italy

2 PhD Rheumatology Unit, Department of Medicine, Surgery and Neuroscience, University of Siena, Italy

CORRESPONDENTE

Antonella Fioravanti Rheumatology Unit, Department of Medicine, Surgery and Neuroscience, University of Siena Viale Bracci 1 - 53100 Siena, Italy Phone: ++390577 233345 Fax: ++390577 40450 Mobile: 3495533262

E - M A I L

fioravanti7@virgilio.it

Recebido: 20/02/2014

Aprovado: 21/05/2014 


\section{INTRODUCTION}

Recent treatment regimens of some chronic rheumatic diseases (RD) comprise multimodal concepts including pharmacologic, physical/exercise, occupational and psychological therapies to support the long-term management of disease. Spa therapy is widely used for musculoskeletal system disorders, such as low back pain, Fibromyalgia or Osteoarthritis (OA) ${ }^{1}$. Thermal therapy is very popular in many European and Middle Eastern countries, as well as in Japan and Israel. This treatment comprises a broad spectrum of therapeutic modalities including hydrotherapy, balneotherapy, physiotherapy, mud-pack therapy and exercise ${ }^{2-4}$. Nowadays it represents auseful alternative to the pharmacological therapy, because of problems related to the use of drugs that often have significant side effects and the occasional lack of valid therapeutic strategies ${ }^{5-8}$.

The efficacy of spa treatments in RD has been bolstered by ancient tradition, but in spite of their long history and popularity, only a few randomized, controlled trials on the use of these therapies in patients with $\mathrm{RD}$ have been conducted and this topic is still the subject of debate and its role in modern medicine continues to be unclear ${ }^{9}$.

The aim of spa therapy is to reduce pain, relieve muscle spasms and improve muscle strength and functional mobility ${ }^{2,3}$.

The action mechanisms of mud packs and thermal baths are not completely known, and it is difficult to distinguish the effects of thermal applications from the benefits that could be derived from a stay in a spa environment ${ }^{2}$.

Although the results of the existing studies are not strong enough to draw firm conclusions, it is necessary to ask what real medical and scientific value these therapies have. The objective of this review is to summarize the currently available information on mechanism of action and possible effects of balneotherapy in RD. We also provide some suggestions for further development in this area.

\section{MECHANISMS OF ACTION \\ OF BALNEOTHERAPY IN RHEUMATIC DISEASES}

The mechanisms by which immersion in thermal mineral water alleviates suffering in $\mathrm{RD}$ are not fully understood. The net benefit is probably the result of a combination of factors, among which the mechanical, thermal and chemical effects are most prominent ${ }^{2}$.

A distinction can be made between the nonspecific (hydrotherapeutic in a broad sense) mechanisms common to simple baths in hot tap water, and specific (hydromineral and crenotherapeutic) mechanisms, which depend on the chemical and physical properties of the water used. While the former are well known, the latter are difficult to identify and assess ${ }^{2}$.

\subsection{Mechanical, thermal and chemical effects}

Balneotherapy may have beneficial effects on muscle tone, joint mobility, and pain intensity.

Increased buoyancy and hydrostatic pressure during immersion in thermal mineral water cause many physiologic changes. Immersion to the suprasternal notch in mineral water $\left(35^{\circ} \mathrm{C}\right)$ results in a cascade of reactions including increased diuresis, natriuresis, and cardiac output ${ }^{10-12}$. The basis of these physiological effects is considered to be the hydrostatic pressure, which forces approximately $700 \mathrm{ml}$ from the lower extremities to the central compartment. Distension of the volume receptors by this central hypervolemia is regarded as the trigger for the observed physiological effects ${ }^{10-12}$.

The effects of thermal baths are partially related to temperature. Hot stimuli may influence muscle tone and pain intensity, helping to reduce muscle spasm and to increase the pain threshold in nerve endings. According to the "gate theory", pain relief may be due to the temperature and hydrostatic pressure of water on the skin ${ }^{13}$.

Thermal stress provokes a series of neuroendocrine reactions. In particular, the heat stimulates the release of adrenocorticotropic hormone (ACTH), cortisol, prolactin and growth hormone (GH), al- 
though it does not alter the circadian rhythm of these hormones ${ }^{14}$.

The effect of thermal stress on the hypothalamus-pituitary-adrenal axis seems to be particularly important for the antiedemigenous and antiinflammatory actions of corticosteroids, as well as for the frequent alteration of the axis during some rheumatic diseases ${ }^{15}$. The increase in beta-endorphin demonstrated to occur with various spa therapy techniques ${ }^{16,17}$ has an analgesic and anti-spastic effect that is particularly important in patients for whom pain is the prevalent symptom.

Recent data have demonstrated the possibility that normal keratinocytes can produce and secrete a precursor pro-opiomelanocortin (POMC) following various stimuli (e.g. ultraviolet rays, thermal stimuli) which is the common precursor of various endorphins ${ }^{18}$. Additionaly, various authors demonstated that the $\beta$-endorphin released into the blood during UV exposure may reach the brain in sufficient concentrations to induce mood enhancement and relaxation ${ }^{19}$. This finding allows us to formulate the fascinating hypothesis that ultraviolet radiation or thermal stimuli could be used to condition the skin's production of opioid peptides, thus altering the personal emotional sphere or pain threshold.If we add that $B$-endorphin also have immunomodulatory effects ${ }^{20}$, the hypothesis of a close correlation between balneotherapy and the psychoneuroendocrine system becomes increasingly convincing.

Furthermore, hyperthermia play an important role on immune system function (see below).

Hyperthermia also has many effects on granulocytes. Heat increases their mobility, phagocytic and bactericidal properties and enzymatic activity ${ }^{2}$.

Furthermore, thermal stimulation increases the extensibility of collagen-rich tissues, such as tendons, fasciae and articular capsules, which may improve the range of motion of joints ${ }^{2}$.

The effects described make it possible to break the vicious circle of pain-muscle contraction-altered joint dynamics-pain that characterizes many chronic arthropathies. The reduction of muscle tone and better use of joints represent just two of the most important elements that show the medium and long-term beneficial effects documented in various clinical studies ${ }^{21-29}$.

The chemical effects of mud-packs and balneotherapy are less clear than the physical effects. In theory, it cannot be excluded that the organic substances or minerals of water or mud, sometimes present in traces, can be absorbed through the skin and then act at a systemic level. However, experimental evidence available in this field are scarce. Shani et $\mathrm{al}^{30}$ (1985) documented a significant increase in serum concentrations of bromine, rubidium, calcium and zinc in patients with psoriatic arthritis who bathed in the Dead Sea. The penetration of the solutes is presumably influenced by the length of bathing time, the temperature of the thermal water, its composition and other factors, some of which may still be unknown. Furthermore, it has been reported that the direct application of mud-pack has greater clinical effects than the application of nylon covered mud pack in patients with knee $\mathrm{OA}^{31}$.

\subsection{Immunologic aspects}

Since sulphur baths have been successfully used in various skin immunomediated afflictions, it has been suggested that absorption through the skin of trace elements present in mineral water and mud packs may affect the immune system ${ }^{32}$.

Overall, thermal stress has an immunosuppressive effect. With regard to hyperthermia a stimulatory effect of the immune response appear to prevail at a moderate increase of local skin temperature, with increase of pro-inflammatory cytokines interleukin (IL) $-6^{33}$ and IL- $1{ }^{34}$, whereas higher temperatures $\left(40-41^{\circ} \mathrm{C}\right)$ apparently suppress immune functions ${ }^{35,36}$.

A significant reduction in circulating levels of T-lymphocytes has been demonstrated in healthy volunteers treated with hyperthermal baths ${ }^{2}$ and in patients with respiratory and cutaneous atopy ${ }^{37}$. Hyperthermia-induced T-lymphocytopenia and eosinopenia may be due to a redistribution of the cells, probably due to the increase of ACTH and cortisol provoked by thermal stress ${ }^{14}$. 
In vitro studies have demonstrated that sulphurous waters have a dose-dependent inhibitory effect on the blast transformation and proliferation of $\mathrm{T}$ lymphocytes obtained from peripheral blood in both healthy subjects and subjects affected by chronic inflammatory diseases ${ }^{37}$. On the other hand, immersion in thermal waters at a temperature of $40^{\circ} \mathrm{C}$ reduces the lymphocyte response to phytohaemoagglutinin ${ }^{38}$. Sulphurous waters also seem to exert a potent inhibitory action on the production of cytokines, especially IL-2 and interferon gamma (IFN- $\gamma$ ). As these cytokines are mainly produced by $\mathrm{CD} 4^{+}$lymphocytes, it can be hypothesized that memory $\mathrm{T}$ cells are the principal target of sulphur-rich waters. The application of sulphurous waters reduces the capacity of memory $T$ cells to proliferate and produce cytokines, thus resulting in an alteration of immune response ${ }^{39}$. The hyperthermia-induced alterations of the cytokine milieu has been recently confirmed in patients affected by ankylosing spondylitis (AS) ${ }^{40}$. Tarner et $\mathrm{al}^{40}$ (2009) showed that the serum levels of tumor necrosis factor (TNF)- $\alpha$, IL- $1 \beta$ and IL- 6 which were measured before, during and after whole-body hyperthermia, were significantly reduced in patients with AS whereas the changes in healthy subjects did not reach statistical significance.

\subsection{Anti-inflammatory and chondroprotective aspects}

Recent studies have shown a reduction of circulating levels of Prostaglandin E2 (PGE2) and Leukotriene B4 (LTB4), important mediators of inflammation and pain, in patients suffering from $\mathrm{OA}$ or fibromyalgia who undergo mud-packs or balneotherapy ${ }^{41,42}$ (Table 1).

Crenotherapy also affects the synthesis of various cytokines involved in the ongoing chondrolysis and inflammation in $\mathrm{RD}$; in fact a reduction in the cytokines IL-1ß and TNF- $\alpha$ and the soluble receptors of the latter has been demonstrated following a cycle of mud baths therapy (temperature $>41 \mathrm{C}^{\circ}$ ) in patients with $\mathrm{OA}^{43-45}$ (Table 1).
Table 1. Effect of thermal mineral baths on various mediators or factor of inflammation, immune response and chondrolysis.

1. Reduction of circulating levels of PGE2 and LTB4 (Ref. 41,42)

2. Reduction of TNF- $\alpha$, IL-6, IL-1 $\beta$ circulating levels (Ref. 40, 43-45)

3. Increase of circulating levels of IGF1 (Ref. 48)

4. Increase in circulating levels of TGF- $B$ (exercise, hyperthermia and exposure to low doses of radon) (Ref. 49)

5. Reduction of the release of ROS and the RNS by PMNs stimulated with $\mathrm{N}$-formyl-methionyl-leucyl-phenylalanine and phorbol-12-myristate-13-acetate (Ref.51)

6. Decrease in NO circulating levels (Ref. 55)

PGE2 = prostaglandin E2; LTB4 = leukotriene B4; TNF- $\alpha=$ tumor necrosis factor- $\alpha$; IL- $6=$ interleukin 6 ; IL-1 $\beta=$ interleukin- $1 \beta ;$ IGF1 = Insulin-like Growth Factor 1; TGF- $\beta=$ Transforming Growth Factor-beta; $\mathrm{ROS}$ = reactive oxygen species; $\mathrm{RNS}=$ reactive nitrogen species; $\mathrm{PMNs}=$ polymorphonucleate leukocytes; $\mathrm{NO}=$ nitric oxide.

Several studies have provided evidence for a significant role of matrix metalloproteinases (MMPs), particularly MMP-3 or stromelysin-1, produced by activated chondrocytes and other cell types in the development of cartilage degradation in joint diseases ${ }^{46}$. A recent study of Bellometti et al ${ }^{47}$ (2005) shown that MMP-3 serum levels were significantly reduced by mud-bath therapy in patient with OA.

Cycles of mud applications and balneotherapy also bring about an increase in some growth factors, such as Insulin-like Growth Factor 1 (IGF1) ${ }^{44}$, which stimulates cartilage anabolism ${ }^{48}$. Furthermore, a significant increase in circulating levels of Transforming Growth Factor-beta (TGF- $\beta$ ) has been found in patients with AS after a combined spa-exercise therapy (exercise, hyperthermia and exposure to low doses of radon) ${ }^{49}$ (Table 1 ). TGF- $B$ is a very potent immunomodulating and anti-inflammatory cytokine which plays a major role in tissue healing, bone remodelling and fibrosis ${ }^{49}$.

Among the various factors responsible for inflammatory and degenerative phenomena in joint during different $R D$, reactive oxygen species (ROS) and nitric oxide (NO) should be taken into consideration ${ }^{50}$.

Sulphurous waters have been demonstrated to have an antioxidant effect in vitro; in fact the incubation in sulphurous mineral water significantly reduces the re- 
lease of ROS and the reactive nitrogen species (RNS) peroxynitrite by polymorphonucleate leukocytes (PMNs) stimulated with $\mathrm{N}$-formyl-methionyl-leucylphenylalanine and phorbol-12-myristate-13-acetate ${ }^{51}$. Various studies in humans have highlighted the positive action of mud-packs and thermal baths, especially sulphurous ones, on the oxidant/antioxidant system. Grabski et al ${ }^{52}$ (2004) reported the reduction of superoxide dismutase (SOD) activity in patients with rheumatoid arthritis (RA) undergoing treatment with sulphuric water. Eckmekcioglu et al ${ }^{53}$ (2002) demonstrated that 3 weeks of sulphur baths can reduce the antioxidative defence system (SOD and glutathione (GSH) peroxidase) in the blood of patients with OA. They discussed that the decline of these enzyme- activities may be caused by two reasons: either as consequence of reduced oxidative stress during sulphur therapy leading to a lower expression of these enzymes or as an enhanced generation of superoxide radicals exhausting the superoxide scavenging enzyme.

Bender et al ${ }^{54}$ (2007) demonstrated that therapeutic baths in mineral water reduced the activity of catalase, SOD, malondialdehyde (MDA) and GSH peroxidase.Other authors have observed a significant decrease in NO and myeloperoxidase (MPO) and a slight increase in GSH peroxidase in the sera of subjects with OA undergoing cycles of mud applications and balneotherapy ${ }^{55}$.

In a recent study we assessed the possible modifications of plasma levels of leptin and adiponectin in patients with $\mathrm{OA}$ treated with a cycle of mud-bath therapy ${ }^{56}$. Our data showed at the end of the therapy, a slight but not significant increase of plasma leptin concentrations and a significant decrease in serum adiponectin levels. These adipocytokines play an important role in the pathophysiology of $\mathrm{OA}^{57}$. In particular, there is some evidence that adiponectin in skeletal joints may have proinflammatory effects and may be involved in cartilage degradation ${ }^{58}$. In view of these recent findings, the decrease of adiponectin after spa therapy demonstrated in our study may play a protective role in OA.

Partial contradictory data were observed in a recent pilot study conducted by Shimodozono et al ${ }^{59}$
(2012). The authors reported a significant increase of serum levels of Leptin in 7 healthy men after a single 10-minute warm-water bath (WWB) at $41^{\circ} \mathrm{C}$ with tap water or WWB with inorganic salts and carbon dioxide $\left(\mathrm{ISCO}_{2}\right)$, and remained significantly higher than those at baseline even 30 minutes after WWB with tap water; serum levels of Adiponectin showed a slight, but not significant, increase immediately and 30 minutes after a single WWB under both conditions. These differences might be due to the difference in subjects (relatively healthy, young, lean and male in this last study) and in modalities of bathing (duration of thermal stimulation and the substances used in the mineral water).

Experimental studies in animal models of arthritis corroborate the evidence of beneficial effects of mud-bath therapy on inflammatory and degenerative joint diseases. Cozzi et al ${ }^{60}$ (2004) have recently demonstrated an anti-inflammatory effect of mud-bath applications in Freund's adjuvant-induced arthritis in rats. In 2007 Britschka et al ${ }^{61}$ (2007) confirmed the anti-inflammatory and chondroprotective effects of the application of mud in Zymosan-induced arthritis in rats, by performing histological analysis on synovial tissues and cartilage taken from the sacrificed animals on day 21 of treatment.

The possible chondroprotective role of mineral water or mineral components was confirmed by some pilot "in vitro" studies in chondrocyte cultures. Burguera et al ${ }^{62}$ (2012), in 2012 studied the possible activity of hydrogen sulphide $\left(\mathrm{H}_{2} \mathrm{~S}\right)$ as an anti-inflammatory and anti-oxidant agent in human osteoarthritic articular chondrocytes stimulated with IL-1 $\beta$. They analyzed the effects of different concentrations of a fast (NaHS) or a slow (GYY4137) release $\mathrm{H}_{2} \mathrm{~S}$ donor on three key aspects of the inflammatory process in OA. The Authors demonstrated a significant reduction of $\mathrm{NO}$ and inducible Nitric Oxide Synthase (iNOS) gene expression, PGE-2, and ROS levels induced by IL-1 $\beta$ in culture medium, after incubation with $\mathrm{H}_{2} \mathrm{~S}$ donors.

A recent study by Fioravanti et al ${ }^{63}$ (2013) showed similar results in human OA chondrocytes cultivated with mineral Vetriolo's thermal water (VW) in the presence or in the absence of IL-1 $\beta$. OA chondrocytes were cultivated in Deionized Water (DW) (DW-DMEM, con- 
trols), or in one of three different VW-DMEM media, in which DW had been totally $(100 \%)$ or in part $(50 \%$ or $25 \%)$ substituted with VW.The results showed that VW alone at $25 \%$ or $50 \%$ concentration did not affect the viability of cultured OA chondrocytes, and determined a significant survival recovery rate in cultures stimulated with IL-1 $1 \beta$. On the contrary, the VW alone at $100 \%$ of concentration reduced, in a significant $(\mathrm{P}<0.05)$ manner, the cells viability. NO levels were low both in DW-DMEM cultures and in those reconstituted with $25 \%$ or $50 \%$ of $\mathrm{VW}$, and were significantly $(\mathrm{P}<0.05)$ increased in cultures with $100 \%$ of VW. VW at $25 \%$ or $50 \%$ concentration significantly $(\mathrm{P}<0.001)$ reduced the NO production induced by IL- $1 \beta$. The data of the NO levels were confirmed by the immunocytochemistry assay for iNOS. Furthermore, the Authors confirmed the pro-apoptotic effect of IL-1 $\beta$ and demonstrated a protective effect of VW at $25 \%$ or $50 \%$ concentration.

\subsection{Other effects of balneotherapy}

Many other non-specific factors may also contribute to the beneficial effects observed after balneotherapy in some RD, including effects on cardiovascular risk factors.

The lipid normalizing effects of balneotherapy, especially with sulphurous waters, have been reported for decades. The results of such research have documented reductions in total cholesterol, triglycerides and nonesterified cholesterol and a significant increase in HDL- cholesterol ${ }^{64}$.

More recently, attention has focused on plasma homocysteine, a risk factor for coronary heart disease, congestive heart failure, systolic hypertension, artherothrombotic events, complications in diabetes mellitus, cancer and oxidative stress ${ }^{65-68}$.A significant reduction in plasma homocysteine has been demonstrated in OA patients after a cycle of sulphurous thermal baths ${ }^{69}$.

Recently Oláh et al ${ }^{70}$ (2010) explored changes in several cardiovascular risk factors in a group of patients suffering from degenerative musculoskeletal disorders subjected to a cycle of balneotherapy. For the first one, the Authors showed a statistically significant and lasting (3 months after the cycle of balneotherapy) decrease in serum levels of high- sensitivity C-reactive protein (hs-CRP) in patients treated with mineral thermal baths.

Always Oláh et $\mathrm{al}^{71}$ (2011) in a consecutive study explored the changes of antioxidant, inflammatory and metabolic parameters in obese and hypertension people after balneotherapy. This study showed that balneotherapy is a safe therapeutic option in hypertension and obesity and that it improved some metabolic and inflammatory markers, such as hsCRP on haemoglobin $\mathrm{A}_{1 \mathrm{C}}$ levels.

The reduction of cardiovascular risk factors through mud-packs and balneotherapy is especially important considering the clear and much-stressed association between various $\mathrm{RD}$ and atherosclerotic processes ${ }^{72}$.

Finally, other elements need to be taken into consideration concerning the mechanisms of action of mud applications and balneotherapy in $\mathrm{RD}$, such as the particular climatic and environmental conditions of spas and the fact that people rest more and are far from daily stress during stays at spa resorts ${ }^{2,3}$.

\section{CONCLUSIONS}

In this review we have underlined the effects of balneotherapy and mud applications on various mediators or factors of inflammation, immune response and chondrolysis. Although the data presented are stimulating, it is impossible to ignore the existence of a complex series of problems and uncertainties that prevent spa therapies from gaining the full consensus of the scientific community ${ }^{9}$. One of the critical points is the controversial problem of the absorption of the minerals dissolved in thermal waters, e.g. the demonstration of specific effects other than those linked to the simple action of heat. Unfortunately few studies have been conducted on this topic and little is known about the specific effects of various mineral waters. It is still not clear which elements are essential and what is the ideal concentration of each element in order to attain an optimal response to treatment. It remains to be clarified which mineral waters are most suitable for various diseases and whether the different components exert specific actions. Such evidence would lead to a specialization of spa resorts, which could finally target their therapies more accurately and rationally. 
Furthermore, the results reported only refer to short term modifications of various mediators of inflammation, immune response and chondrolysis, lasting until the end of the cycle, and little is known of the possible long term effects. This is a key element in seeking to explain the persistence of the symptomatic benefit induced by such thera-

\section{FONTE DE FINANCIAMENTO}

Nenhuma

\section{CONFLITO DE INTERESSES}

\author{
Declara não haver
}

\section{REFERENCES}

1. Annegret F., Thomas F, Long-term benefits of radon spa therapy in rheumatic diseases: results of the randomised, multi-centre IMuRa trial. Rheumatol. Int. 2013 Nov;33(11):2839-2850.

2. Sukenik S., Flusser D., Abu-Shakra M., The role of SPA therapy in various rheumatic diseases. Rheum. Dis. North. Am. 1999 Nov;25(4):883-897.

3. Bender T., Karagülle Z., Bàlint GP., Gutenbrunner C., Bàlint PV., Sukenik S.,Hydrotherapy, balneotherapy, and spa treatment in pain management. Rheumatol. Int. 2005 Apr;25(3):220-224.

4. Nicholas JJ., Physical modalities in rheumatological rehabilitation. Arch. Phys.Med. Rehabil. 1999 Sep;75(9):994-1001.

5. Ofman JJ., Maclean CH., Straus WL., Morton SC., Berger ML., Roth EA., et al. A meta-analysis of severe upper gastrointestinal complications of nonsteroidal anti-inflammatory drugs. J Rheumatol. 2002 Apr;29(4):804-812.

6. Bresalier RS., Sandler RS., Quan H., Bolognese JA., Oxenius B., Horgan K., et al. Trial investigations: cardiovascular events associated with rofecoxib in a colorectal adenoma chemoprevention trial. N Engl J Med. 2005 Mar;352(11):1092-1102.

7. Kearney PM., Baigent C., Godwin J., Halls H., Emberson JR., Patrono C. Do selective cyclo-oxygenase-2 inhibitors and traditional non-steroidal anti-inflammatory drugs increase the risk of atherothrombosis? Meta-analysis of randomised trials. BMJ. 2006 Jun;332(7553):1302-1308.

8. Zhang W., Jones A., Doherty M., Does paracetamol (acetaminophen) reduce the pain of osteoarthritis?: a meta-analysis of randomised controlled trials. Ann Rheum Dis. 2004 Aug;63(8):901-907.

9. Verhagen AP., Bierma-Zeinstra SMA., Boers M., Cardoso JR., Lambeck J., de Bie RA, et al. Balneotherapy for osteoarthritis. Cochrane database of systemic reviews. 2007 Oct;17;(4):CD006864.

10. O'Hare JP., Heywood A., Summerhayes C., Lunn G., Evans JM., Walters G., et al. Observation on the effects of the immersion in bath spa water. Br Med J. 1985 Dec;291(6511):1747-1751.

11. Weston CFM., O’Hare JP., Evans JM., Corrall RJ., Haemodynamic changes in man during immersion in water at different temperatures. Clin Sci. 1987 Dec;73(6):613-616.

12. Epstein M., Renal effects of head-out water immersion in humans: a 15 year update. Physiol Rev. 1992 Jul;72(3):563-621.

13. Melzack R., Wall PD., Pain mechanism: a new theory. Science. 1965 Nov; 150(3699):971-979.

14. Kuczera M., Kokot F., The influence of SPA therapy on endocrine system. Stress reaction hormones. Pol Arch Med Wewn. 1996 Jan;95(1):11-20.

15. Gur A., Cevik R., Sarac AJ., Colpan L., Em S., Hypothalamicpituitary-gonadal axis and cortisol in young women with primary fibromyalgia: the potential roles of depression, fatigue, and sleep disturbance in the occurrence of hypocortisolism. Ann Rheum Dis. 2004 Nov; 63(11):1504-1506. pies in some $\mathrm{RD}$, as shown in long term controlled clinical trials ${ }^{21-29}$.

In conclusion, existing researches are stimulating, but are not sufficiently strong to draw firm conclusions. More studies are needed to help draw firm conclusions regarding the mechanisms of actions of balneotherapy in various $\mathrm{RD}$.

16. Kubota K., Kukabayashi H., Tamura K., Kawada E., Tamura J., Shirakura T., A transient rise in plasma b-endorphin after a traditional $47^{\circ} \mathrm{C}$ hot-spring bath in Kusatsu-spa, Japan. Life Sci. 1992;51(24):1877-1901.

17. Cozzi F., Lazzarin I., Todesco S., Cima L., Hypotalamic pituaryadrenal axis dysregulation in healthy subjects undergoing mudbath-applications. Arthritis Rheum. 1995 May;38(5):724-725.

18. Ghersetich I., Freedman D., Lotti T., Balneology today. J Eur Acad Dermatol Venereol. 2000 Sep;14(5):346-348.

19. Juzeniene A, Moan J. Beneficial effects of UV radiation other than via vitamin $\mathrm{D}$ production.

20. Dermatoendocrinol. 2012 Apr; 4(2):109-117.

21. Berczi I., Chalmers IM., Nagy E., Warrington RJ., The immune effects of neuropeptides. Baillieres Clin Rheumatol 1996 May;10(2):227-257.

22. Guillemin F., Constant F., Collin JF., Boulange M., Short and long-term effect of Spa therapy in chronic low back pain. Br J Rheumatol. 1994 Feb;33(2):148-151

23. Nguyen M., Revel M., Dougados M., Prolonged effects of 3 weeks therapy in a Spa resort on lumbar spine, knee and hip osteoarthritis: follow up after 6 months. A randomized controlled trial. Br J Rheumatol 1997; 36:77-81.

24. Elkayam O., Ophir J., Brener S., Paran D., Wigler I., Efron D., et al. Immediate and delayed effects of treatment at the Dead Sea in patients with psoriasis arthritis. Rheumatol Int. 2000;19(3):77-82.

25. van Tubergen A., Landewé R., van der Hetijede D., Hidding A., Wolter N., Asscher M., et al.,Combined Spa-Exercise therapy is effective in patients with ankylosing spondylitis: a randomized controlled trial. Arthritis Care Res. 2001 Oct;45)5):430-438

26. Cantarini L., Leo G., Giannitti C., Cevenini G., Barberini P., Fioravanti A., Therapeutic effect of spa therapy and short wave therapy in knee osteoarthritis: a randomized, single blind, controlled trial. Rheumatol Int. 2007 Apr; 27(6):523-529.

27. Fioravanti A., Perpignano G., Tirri G., Cardinale G., Giannitti C., Lanza CE., et al., Effects of mud-bath treatment on fibromyalgia patients: a randomized clinical trial. Rheumatol Int. 2007 Oct;27(12):1157-1161.

28. Harzy T., Ghani N., Akasbi N., Bono W., Nejjari C., Short- and long-term therapeutic effects of thermal mineral waters in knee osteoarthritis: a systematic review of randomized controlled trials. Clin Rheumatol. 2009 May;28(5):501-507.

29. Forestier R., Desfour H., Tessier J-M., Francon A., Foote AM., Genty C., et al., Spa therapy in the treatment of knee osteoarthritis, a large randomised multicentre trial.Ann Rheum Dis. 2009 Apr;69(4):660-665.

30. Fioravanti A., Iacoponi F., Bellisai B., Cantarini L., Galeazzi M., Short and Long-Term Effect of Spa Therapy in Knee Osteoarthritis. Am J Phys Med Rehabil. 2010 Feb;89(2):125-132. 
31. Shani J., Barak S., Levi D., Ram M., Schachner R., Schlesinger T., et al.,Skin penetration of minerals in psoriatics and guinea pigs bathing in hypertonic salt solutions. Pharmacol Res. 1985 Jun;17(6):501-506.

32. Odabasi E., Turan M., Erdem H., Tekbas F.,Does mud pack treatment have any clinical effect? A randomized controlled clinical study. J Altern Complement Med. 2008 Jun;14(5):559-5565.

33. Sukenik S., Abu-Shakra M., Flusser D., Balneotherapy in autoimmune diseases. Isr J Med Sci. 1997 Apr;33(4):258-261.

34. Sobieska M., Stratz T., Samborski W., et al., Interleukin-6 (IL-6) after whole body cryotherapy and local hot mud pack treatment. Eur J Phys Med Rehabil. 1993;3:205.

35. Olszewski WL., Grzelak I., Ziolkowska A., Engeset A., Effect of local hyperthermia on lymph immune cells and lymphokines of normal human skin. J Surg Oncol. 1989 Jun;41(2):109-116.

36. Schmidt KL., Simon E., Thermotherapy of pain, trauma and inflammatory and degenerative rheumatic diseases. Thermotherapy for Neoplasia, Inflammation and Pain. Springer. 2001;527-539.

37. Lange U., Müller-Ladner U., Schmidt KL., Balneotherapy in rheumatic diseases-an overview of novel and known aspects. Rheumatol Int. 2006 Apr;26(6):497-499.

38. Valitutti S., Costellino F., Musiani P., Effect of sulfurous (thermal) water on T lymphocyte proliferative response. Ann Allergy. 1990 Dec;65(6):463-468.

39. Smith JB., Knowlton RP., Agarwal SS., Human lymphocyte responses are enhanced by culture at $40^{\circ} \mathrm{C}$. J Immunol. 1978 Aug;121(2):691-696.

40. Ghersetic I., Lotti T., Immunologic aspects: immunology of mineral waters. Clin Dermatol. 1996 Nov-Dec;14(6):563-566.

41. Tarner IH., Müller- Ladner U., Uhlemann C., Lange U., The effect of mild whole-body hyperthermia on systemic levels of TNF-alpha, IL-1 beta, and IL-6 in patients with ankylosing spondylitis. Clin Rheumatol. 2009 Apr;28(4):397-402.

42. Bellometti S., Galzigna L., Serum levels of a prostaglandin and a leukotriene after termal mud-pack therapy. J Invest Med. 1998 Apr;46(4):140-145.

43. Ardiç F., Ozgen M., Aybek H.,Rota S., Cubukçu D., G凶kg冈z A., Effect of balneotherapy on serum IL-1, PGE 2 and $\mathrm{LTB}_{4}$ levels in fibromyalgia patients. Rheumatol Int. 2007 Mar;27(5):441-446.

44. Cecchettin M., Bellometti S., Lalli A., Galzigna L.,Serum interleukin 1 changes in arthrosic patients after mud-pack treatment. Phys Rheab Kur Med. 1995;5:92-93.

45. Bellometti S., Cecchettin M., Galzigna L., Mud-pack therapy in osteoarthrosis changes levels of chondrocytes markers. Clin Chim Acta.1997 Dec;268(1-2):101-106.

46. Bellometti S., Galzigna L., Richelmi P., Gregotti C., Bertè F., Both serum receptors of tumor necrosis factor are influenced by mud pack treatment in osteoarthrotic patients. Int J Tissue React. 2002;24(2):57-64.

47. Lohmander LS., Hoermer LA., Lark MV., Metalloproteinases, tissue inhibitor, and proteoglycan fragments in kneesynovial fluid in human osteoarthritis. Arthritis Rheum. 1993 Feb;36(2):181-189.

48. Bellometti S., Richelmi P., Tassoni T., Bertè F., Production of matrix metalloproteinases and their inhibitors in osteoarthritic patients undergoing mud bath therapy. Int J ClinPharm Res. 2005;25(2):77-94.

49. Trippel SB., Growth factor action on articular cartilage. J Rheumatol. 1995 Feb;43:129-132.

50. Shehata M., Schwarzmeier JD., Hilgarth M., Demirtas D., Richter D. Hubmann R., et al. Effect of combined spa-exercise on circulating TGF- $B 1$ levels in patients with ankylosing spondylitis. Wien Klin Wochenschr. 2006 May;118(9-10):266-272.

51. Farrell AJ., Blake DR., Palmer RM., Moncada S., Increased concentrations of nitrite in synovial fluid and serum samples suggest increased nitric oxide synthesis in rheumatic diseases. Ann Rheum Dis.1992 Nov;51(11):1219-1222.

52. Braga PC., Sambataro G., Dal Sasso M., Culici M., Alfieri M., Nappi G., Antioxidant effect of sulphurous thermal water on human neutrophil bursts: chemiluminescence evaluation. Respiration. 2008 Sep;75(2):193-201

53. Grabski M., Wozakowska-Kaplon B., Kedziora J., Hydrogen sulphide water balneum effect on erythrocyte superoxide dismutase activity in patients with rheumatoid arthritis-in vitro study. Przegl Lek. 2004;61(12):1405-1409.
54. Eckmekcioglu C., Strauss-Blasche G., Holzer F., Marktl W., Effect of sulfur baths on antioxidative defense systems, peroxide concentrations and lipid levels in patients with degenerative osteoarthritis. Forsch Komplementarmed Klass Naturheilkd. 2002 Aug;9(4):216-220.

55. Bender T., Bariska J., Vàghy R., Gomez R., Imre K. Effect of balneotherapy on the Antoxidant System - A controlled pilot study Arch Med Res. 2007 Jan;38(1):86-89.

56. Bellometti S., Poletto M., Gregotti C., Richelmi P., Bertè F., Mud bath therapy influences nitric-oxide, myeloperoxidase and glutathione peroxidase serum levels in arthritic patients. Int J Clin Pharmacol Res.2000;20(3-4):69-80.

57. Fioravanti A., Cantarini L., Bacarelli MR., de Lalla A, Ceccatelli L., Blardi P.,Effects of spa therapy on serum leptin and adiponectin levels in patients with knee osteoarthritis. Rheumatol Int. 2011 Jul;31(7):879-882.

58. Lago R., Gomez R., Otero M., Lago F., Gallego R., Dieguez C., et al.,A new player in cartilage homeostasis: adiponectin induces nitric oxide synthase type II and pro-inflammatory cytokines in chondrocytes. Osteoarthritis Cartilage. 2008 Sep;16(9):1101-1109.

59. Gomez R., Lago F., Gomez-Reino J., Dieguez C., Gualillo O., Adipokines in the skeleton: influence on cartilage function and joint degenerative diseases. J Mol Endocrinol. 2009 Jul;43(1):11-18.

60. Shimodozono M., Matsumoto S., Ninomiya K., Miyata R., Ogata A Etoh S., et al., Acute effects of a single warm-water bath on serum adiponectin and leptin levels in healty men: a pilot study. Int J Biometeorol. 2012 Sep;56(5):933-939.

61. Cozzi F., Carrara M., Sfriso P., Todesco S., Cima L., Antiinflammatory effect of mud-bath applications on adjuvant arthritis in rats. Clin Exp Rheumatol. 2004 Nov-Dec;22(6):763-766.

62. Britschka ZMN., Teodoro WR., Velosa AP., de Mello SB.,The effect of Brazilian black mud treatment in chronic experimental arthritis. Rheumatol Int. 2007 Nov;28(1):39-45.

63. Burguera EF., Anero AV., Falide RM., Blanco FJ.,The effect of hydrogen sulfide donors on inflammatory mediators in human articular osteoarthritic chondrocytes. Arthritis Rheum. 2012;64 Suppl 10:6.

64. Fioravanti A., Lamboglia A., Pascarelli NA., Cheleschi S., Manica P., Galeazzi M., et al. Thermal water of Vetriolo, Trentino, inhibits the negative effect of interleukin $1 \beta$ on nitric oxide production and apoptosis in human osteoarthritic chondrocytes. J biol Regul Homeost Agents. 2013 Jul-Sep;27(3):891-902.

65. Strauss-Blasche G., Eckmekcioglu C., Leibetseder V., Marktl W.,Seasonal variation of lipid-lowering effects of complex spa therapy.Forsch Komplementarmed Klass Naturheilkd. 2003 Apr;10(2):78-84.

66. Bostom AG., Selhub J., Homocysteine and arteriosclerosis: subclinical and clinical disease associations. Circulation. 1999 May;99(18):2361-2363.

67. Vasan RS., Beiser A., D'Agostino RB., Levy D., Selhub J., Jacques PF., et al. Plasma homocysteine and risk for congestive heart failure in adult without prior myocardial infarction. JAMA. 2003 Mar;289(10):1251-1257.

68. Agullo-Ortuno MT., Albaladejo MD., Parra S., Rodriguez-Manotas M., Fenollar M., Ruìz-Espejo F., et al. Plasmatic homocysteine concentration and its relationship with complications associated to diabetes mellitus. Clin Chim Acta. 2002 Dec;326(1-2):105-112.

69. Sun CF., Haven TR., Wu TL., Tsao KC., Wu JT., Serum total homocysteine increases with the rapid proliferation rate of tumor cells and decline upon cell death: a potential new tumor marker. Clin Chim Acta. 2002 Jul;321(1-2):55-62.

70. Leibetseder V, Strauss-Blasche G, Holzer F, Marktl W, Ekmekcioglu C. Improving homocysteine levels through balneotherapy: effects of sulphur baths. Clin Chim Acta. 2004 May;343(1-2):105-111.

71. Oláh M., Koncz A., Fehér J., Kàlmànczhey J., Oláh C., Balogh S., et al. The effect of balneotherapy on $\mathrm{C}$-reactive protein, serum cholesterol, triglyceride, total antioxidant status and HSP-60 levels. Int J Biometeorol. 2010 May;54(3):249-254.

72. Oláh M., Koncz A., Fehér J., Kàlmànczhey J., Oláh C., Nagy G., et al. The effect of balneotherapy on antioxidant, inflammatory, and metabolic indices in patients with cardiovascular risk factor (hypertension and obesity)- A randomised, controlled, follow-up study. Contemp Clin Trials. 2011 Nov;32(6):793-801.

73. Turesson C., Jacobsson LTH., Matteson EL., Cardiovascular co-morbidity in rheumatic diseases. Vasc Health Risk Manag. 2008;43(3):605-614 